\title{
SPIRITUALITY \\ IN OFFERING A PEACE OFFERING
}

\author{
Nobuyoshi Kiuchi
}

\begin{abstract}
Summary
Study of the symbolic meaning of the offerings in Leviticus has been hampered by the fact that the text rarely spells out the significance of the rituals or rites. This study proposes an approach to the text of Leviticus that, taking the peace offering as an example, investigates the motive of the offerer. On the basis of explicit references in Leviticus 7:12 and 7:16 to three kinds of motive it is argued that Leviticus 3 has the purpose of turning the Israelites to the Lord, and that the shedding of blood symbolises the atonement for general sinfulness. This leads to the conclusion that the motive or purpose of an offerer and the ritual are inseparable, and that the prescriptive text of Leviticus 3 itself assumes that the inner motive of an offerer must be expressed outwardly in making a peace offering.
\end{abstract}

\section{Introduction}

It is taken for granted in scholarship that the offering of a sacrifice has some symbolic meaning. Yet this being so, it seems that in this century, except for some recent significant contributions, ${ }^{1}$ not much advance has been made in the study of the symbolic meaning of sacrifices or of the significance of individual components of their rituals. The difficulty for a modern reader is partly due to the fact that the meaning of the sacrifice or ritual is not sufficiently spelled out, being presupposed by the ancient Israelites. ${ }^{2}$ It is to be hoped that such a study will be pursued in the future.

1 E.g. G.J. Wenham, The Book of Leviticus (Grand Rapids: Eerdmans, 1979); J. Milgrom, Leviticus 1-16 (AB 3; New York: Doubleday, 1991).

2 For a lucid explanation of the matter, see G.J. Wenham, 'The theology of Old Testament sacrifice', in Sacrifice in the Bible, ed. R.T. Beckwith and M.J. Selman (Carlisle: Paternoster, 1995), 75-87. 
However, is it not necessary to view the relationship between a sacrifice and its symbolic meaning in such a way that one regards the heart of a worshipper (his emotion and will) as representing the sacrifice and one does not merely suppose that representation is carried out by the sacrifice and ritual? The representation thus works two ways:

$\begin{array}{lll}\text { sacrifice } & > & \text { purpose of the worshipper } \\ \text { purpose of the worshipper } & > & \text { sacrifice }\end{array}$

Although Leviticus rarely spells out the significance of each ritual or rite, it is agreed that the reason that this is not mentioned is that it was taken for granted by the original readership. ${ }^{3}$ My proposal is that the reverse viewpoint is also useful and even necessary in considering the symbolism of the sacrificial ritual: one should also read the sacrificial text on the assumption that the purpose of a worshipper is or should be expressed in the sacrifice and its ritual.

Indeed, though it is not easy to know the significance of every rite, few would disagree with the idea that offering a sacrifice starts from the worshipper's heart. That is not to say that the worshipper's heart is all that counts. After all, the purpose of the first five chapters of Leviticus is primarily to prescribe how one should offer sacrifices and offerings, i.e. it is a prescriptive text. Nevertheless, it does seem that the text presumes that the sacrifice is dependent upon the attitude of the worshipper. The question is how the purpose of a worshipper is related to the particular sacrifice and its ritual. If the two are intricately connected, then it is also justifiable to suppose that the sacrifice and its ritual are only meaningful if the attitude of the worshipper is right.

To put it another way: how should one assess the text of Leviticus, which deals almost exclusively with the proper way that sacrifices and offerings should be made to the Lord? Is Leviticus concerned only with external acts? As argued above, this is unlikely. The text of Leviticus prescribes how to offer sacrifices and offerings, by and large taking for granted the mind of the worshipper.

It is the purpose of this paper to demonstrate that this viewpoint is not only helpful but also necessary in understanding a sacrificial ritual. I will take as an example the case of שִשְלָמים, here tentatively translated 'peace offering'.

3 Wenham, Leviticus, passim. 


\section{Three kinds of motive}

The ritual of the peace offering is given in chapter 3 of Leviticus. The motive for offering a peace offering is found in Leviticus 7:12 and $7: 16$. There are three kinds of motive: confessional, votive, and freewill. ${ }^{4}$ This means that though Leviticus 3 gives merely the regulations for the ritual, it has presuppositions about the motives of the worshipper. For the sake of the following argument it would be in order to comment on the three Hebrew terms in 7:15-16.

Firstly, it is agreed that תוֹרדה means not 'thanks' but essentially 'confession'. It is important to note that this term does not just denote an emotion, but also refers to an act of confession. The latter varies according to the context. תוֹדָדi is frequently associated with terms related to joy as a response to salvation already given by the Lord (Je. $30: 19$; Pss. 42:5; 95:2; 100:4). But in two occurrences it is related to the confession of sins (Jos. 7:19; Ezr. 10:11, in both the construction being (תוֹדָה + נָתותן). It seems that while the translation 'confession' is essentially right, here in Leviticus 7:12 and 7:16 it could better be translated 'praise', bearing in mind that in all the occurrences associated with praise, thanksgiving and joy. The term refers to a serious and weighty act on the part of the worshipper that comes last in the worship, or if not last, at least after penitence.

In second place, the term נִ ג can be translated 'vow'. The problem with this term is not in how to translate it but how it is related to the following term נדרבָ , which is normally translated 'freewill'. There is little indication of how to differentiate situations in which these two sacrifices are offered. ${ }^{6}$ However, possibly the term refers to a vowed response to the Lord's salvation which has not yet been given, whereas the emphasis of the term נִ דָדבָ lies in spontaneity and does not involve a vow in responding to the Lord. ${ }^{7}$ In other

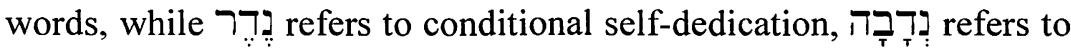
unconditional self-dedication.

At any rate, though they may be mixed with emotions, these three kinds of motive are related to the will of the worshipper.

4 Note that even here at 7:15-16 these three kinds of peace offering are mentioned only incidentally; the main context is about the eating of the remaining meat.

5 Cf. D. Bach, 'Rite et parole dans L'Ancien Testament', VT 28 (1978), 10-19; G. Mayer, דיה in TWAT III, 1982, 456-58.

6 J. Conrad, נדב in TWAT V, 1986, 240-41.

7 J.H. Kurtz, Sacrificial Worship of the Old Testament, Tr. J. Martin (Grand Rapids: Baker, 1980), 259. 
In fact, the importance of the motive of a worshipper is highlighted by the fact that when the offerer wished to confess to the Lord he would have to decide first whether he was going to offer the burnt offering or the peace offering (cf. Lv. 7:15-16; 22:18). Moreover, the worshipper had to decide not just which of the offerings he would like to offer, but also what kind of animal he was going to offer, since similar kinds of animal could be used in both offerings (Lv. 1:3, 10; $3: 1,6,12$ ).

Thus it seems necessary to see the prescriptive text either as expressing the mind of the worshipper, or as given by the Lord who presupposes the worshipper's good will.

Such an understanding of Leviticus 3 indicates that though nothing is mentioned about the subjective side of the worshipper, it is presupposed. But why is it not mentioned? Part of the reason for this is discussed below. However, the significance of the matter is obvious: mere subjective feeling is not sufficient before the Lord. The inner emotion of 'thanks', for example, is not sufficient by itself. It must be expressed in the form of an animal sacrifice.

\section{The purpose of Leviticus 3}

It is well known that the ritual of the peace offering ends with the worshipper eating the rest of the meat. However, this part of the ritual is not mentioned at all in Leviticus 3. It is easily surmised, then, that the purpose of Leviticus 3 was not to prescribe the whole ritual of the peace offering. The fact that not all the ritual components of the peace offering are mentioned in Leviticus 3 suggests that the purpose of Leviticus 3 is to instruct the Israelites to offer the peace offering to the Lord, while presupposing the communal part of the ritual. Deliberately omitting the communal part of the ritual, the text concentrates on the procedure starting from the slaughtering of the animal to the burning of the fat to the Lord.

Now from Leviticus itself (17:4-5) it is known that the Israelites used to offer the sacrifice to the demons in the desert, or just to slaughter outside the sanctuary in order to obtain meat. Therefore it can be inferred that the main purpose of Leviticus 3 is to concentrate on how one should make the peace offering. In fact, the prescription in Leviticus 3 emphasises that the ritual acts ought to be performed 'before YHWH' (vv. 1, 3, 12) and 'to YHWH' (vv. 3, 5, 6, 9, 11, 14, 16). 
On the other hand, such a purpose for Leviticus 3 itself presupposes the inner attitude of the worshipper. That is, when he feels obliged to the Lord for salvation, he is first to offer the peace offering to the Lord to express his thanksgiving. It is reasonable to assume that the ritual acts coram deo require the motive of a worshipper to be identified with slaughtering the sacrifice.

Therefore, it may be inferred that the concentration of Leviticus 3 on the ritual has the basic aim of turning the Israelites to the Lord. There are two further inferences that can be made from this.

First, one's inner impulse towards the Lord must be expressed outwardly in the form of offering sacrifices. One aspect of true spirituality is that worship should not be confined to the heart, but that inner emotion and attitude should be expressed outwardly in the form of sacrifice.

Second, the deliberate omission of the communal part of the ritual seems to instruct the Israelites in the theological truth that inner impulses towards the Lord such as thanksgiving and confession must come before eating meat. No doubt behind this teaching lies a deeper rationale that humans are fed by the Lord (cf. Dt. 8:3).

\section{The blood-shedding}

Why is the shedding of blood required for the peace offering? This is a basic question also common to other sacrificial rituals.

Traditionally, any handling of blood in the sacrificial ritual has been explained by reference to Leviticus 17:11 that postulates that the blood has an atoning effect as life. Although the expiatory function of blood in the case of the תח of the peace offering, sinfulness in a general sense has been assumed for the peace offering. However, J. Milgrom has consistently attacked this position saying that the context of Leviticus 17:11 is about the peace offering, and that the passage itself talks only about the blood of the peace offering. ${ }^{8}$ Space does not allow us here to enter into a detailed examination of the passage. However, strong opposition to Milgrom's view has been voiced to the effect that the passage deals with the meaning of sacrificial blood in general. ${ }^{9}$ In particular, it must

8 J. Milgrom, Studies in Cultic Theology and Terminology (Leiden: Brill, 1983), 96-103.

9 N. Kiuchi, The Purification Offering in the Priestly Literature (JSOTS 56; Sheffield: JSOT Press, 1987), 102-103; J. Hartley, Leviticus (WBC 4; Dallas: Word Books, 1992), 274-75 and the authors cited on p. 275; R. Rendtorff, 
be pointed out that the double use of 'כ in verse 11 produces increasing levels of abstractness, so that the second presents the grand principle in the sacrificial ritual in general. ${ }^{10}$

Given that the blood of the peace offering has an atoning power, how is the joyous character of the peace offering compatible with the sinfulness of the offerer?

Traditionally, it has been postulated that the general sinfulness of an offerer must be removed by blood-shedding, thus enabling him to approach the Lord. This seems essentially correct. However, this same truth may be viewed from a slightly different angle as follows.

Basically a man is put to death if he approaches the holy realm without due qualification (Ex. 19:12; 20:19). In a word, in approaching the Lord, the offerer must experience death. It could be assumed that blood sacrifices are particularly intended to bridge the gap between the holy God and the sinful human, although the degree and the nature of the atonement varies according to the kind of sacrifice involved. The case of the peace offering has least connection with atonement. Yet as long as a peace offering ought to be slaughtered, it functions to atone for the offerer. Thus, in the case of the peace offering as well, the blood should be poured by the altar in order to enable the offerer to approach the Lord.

All this means that a sort of death is required even when a worshipper draws near to the Lord to express his thanksgiving. This suggests that there is more to the peace offering than the joy and thanksgiving of the worshipper.

\section{The peace offering as optional?}

The peace offering, like the burnt offering, has been classified as a voluntary offering as opposed to a mandatory one. ${ }^{11}$ This can be corroborated by the fact that in the case of the peace offering situations anterior to the bringing of an animal are not explicitly

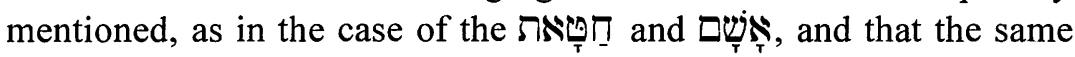
motive on the part of the worshipper (for instance, joy) may not

Leviticus (Biblischer Kommentar: Altes Testament 3/3; Neukirchen-Vluyn: Neukirchener, 1992), 168-69.

10 Cf. W.T. Claassen, 'The speaker-oriented function of 'ִ̣ in Biblical Hebrew, Journal of Northwest Semitic Languages 11 (1983), 29-46.

11 J. Milgrom, IDB Supplement, 763-71, esp. 764; Wenham, Leviticus, 74. See also the critique by R. Knierim, Text and Concept in Leviticus 1:1-9 (Tübingen: J.C.B. Mohr, 1992), 13, no. 17. 
necessarily be expressed by the peace offering, but sometimes by the burnt offering. In other words, the same motive, such as a vow or freewill dedication, can be expressed either by the peace offering or by the burnt offering (Lv. 22:18; Ezk. 46:12). Thus, as far as the worshipper is concerned, it appears optional whether he offers the burnt offering or the peace offering, or whether he offers a sheep or a cow.

However, if the shedding of blood is required to enable him to approach the Lord, it would not be adequate just to classify the peace offering as voluntary. Since the peace offering comes in at least three varieties, we shall briefly consider each in turn.

As mentioned above, the confessional offering presumes that the worshipper has already experienced a salvific act of the Lord. This means that if the offering is meant to express thanksgiving, for instance, it is not optional but obligatory, since it would be a duty to respond to the gracious dealings of the Lord. Moreover, as argued above, תורדָה means an act of confession, and not simply a feeling. In conformity with this Leviticus 7:12 runs as follows:

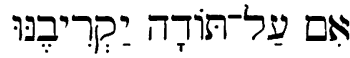

Here עy means 'for' in the sense of design. Therefore the peace offering and the worshipper's purpose are meant to be inseparable. Thus the possibility is precluded that the worshipper has the 'feeling' of thanks but does not express it by offering a peace offering.

The votive offering is evidently obligatory because the worshipper makes a vow that he will offer a peace offering when the Lord responds to his plea or request.

The freewill offering appears optional. However, though 'freewill' means optional, the law appears to presume that an offering of this kind should not be separated from the motive of the offerer. In other words, the possibility that something prompts the worshipper to offer the peace offering, but that he does not offer it, is far from the mind of the lawgiver. The arguments above on Leviticus 7:12 also apply to votive and freewill offerings mentioned in Leviticus 7:16.

Furthermore, when the significance of blood-shedding is taken into consideration, a deeper dimension of the sacrifice emerges. As mentioned above, the blood of the sacrifice enables the worshipper to draw near to the Lord, thus removing the sinfulness of the worshipper. This shows that though the peace offering is often offered to express thanksgiving and joy, the worshipper cannot express these attitudes to the Lord without his sinfulness being removed. Is a situation ever 
envisaged in which the worshipper expresses his thanksgiving simply by words without offering a peace offering? Such a situation certainly seems possible. However, the text of Leviticus appears to say something more about expressing one's thanksgiving: if thanksgiving ought to be expressed by shedding the blood of an animal, then how can mere words suffice, if they are sincere?

From a human standpoint, thanksgiving is not merely optional, it is often a duty, particularly if the salvation a man receives from the Lord is too great to be confined to his own feeling. In fact, the simple fact that the ritual of the peace offering includes the shedding of blood presupposes that the Lord's dealings are always so great and gracious as to require the animal sacrifice from the worshipper.

It can therefore be concluded that the peace offering is optional in the sense that the worshipper is free to choose the peace offering or the burnt offering, or to choose a suitable kind of animal. However, it must be added that to have fellowship with the Lord requires the shedding of blood which symbolises sincere self-dedication on the part of the worshipper. To put it another way, taking the freewill offering as an example, the worshipper is free to choose the kind of offering (the burnt offering or the peace offering) and the kind of animal, but his unconditional self-dedication is possible only when his sinfulness is removed by the shedding of blood.

\section{Conclusion}

The ritual prescriptions for the peace offering appear to the modern reader as a very 'dry' text. However, though that should not be gainsaid, it is highly likely that the 'dry' text is meant to express the purpose and the motive of an offerer.

If this approach is more or less right, the following inferences may be drawn with regard to the spirituality of offering the peace offering:

(1) Mere inner emotion such as 'being thankful' is not enough. It is to be expressed outwardly through offering an animal sacrifice. ${ }^{12}$

(2) There is an intricate bond between the purpose or motive of the offerer and the ritual. Further, given the enormity of sacrifice on the part of the offerer, which is expressed not just by the cost of an animal, but by the shedding of its blood, it is not sufficient merely to

12 Cf. H.-J. Hermisson, Sprache und Ritus im altisraelitischen Kult: Zur Spiritualisierung der Kultbegriffe im Alten Testament (Neukirchen-Vluyn: Neukirchener, 1965). 
say that the peace offering is optional. The implication is that the peace offering ought (rather than 'is expected') to be offered when the offerer makes an acknowledgment to the Lord for his gracious acts.

(3) Far from constituting the seedbed of Pharisaism, it is highly likely that the sacrificial law in Leviticus endorses a rich spiritual relationship between the worshipper and God. The concentration of the text on external ritual acts is not an indication that the worship is external, but it is rather an indication that the lawgiver desires to stress that the worshipper must express his inner attitude outwardly.

If this approach to the peace offering is correct, it will require a reappraisal of the other two kinds of offerings - the burnt offering and the so-called grain offering-and of offerings known in later literature, whether in the prophets' criticisms or in the various evaluations in the Psalms. 